\title{
夣 CONDITIONAL RELEASE AND THE ROLE OF SERVICE FOR TREATMENT IN CRIMINAL LEGISLATION OF THE REPUBLIC OF SERBIA
}

\author{
Zoran Pavlović \\ University Business Academy in Novi Sad, Faculty of Law, Serbia \\ Nikola Petković \\ District Prison, Novi Sad, Serbia \\ Stefan Babović \\ University Business Academy in Novi Sad, Faculty of Law, Serbia
}

\begin{abstract}
onditional release represents a motivational criminal justice institute
that carries an important role in the treatment of persons sentenced to imprisonment. However, the current legal provisions and by-laws seem very problematic in the context of assessing the achievement of criteria, which professional employees in the Department for Treatment and Courts in Serbia use to estimate the educational correction level achieved during the enforcement of a sentence. In this sense, this paper focuses on the logical and empirical analysis of the starting point on which the work of educators in prisons and correctional facilities is based upon, as well as the positive solutions concerning conditional release contained in the Criminal Code. Finally, proposals for amendments to laws and regulations aligning the educators' work with the strict scientific evaluation criteria will be formulated.
\end{abstract}

Key Words: Department for Treatment, parole, individual objectives

\section{Introduction}

Conditional release constitutes a general criminal justice institute of motivational nature that has had a tradition in Serbia for nearly a century and a half. ${ }^{1,2,3}$ The development of penology and criminal enforcement law, and the idea of progressive principles in the execution of a sentence have been influenced by the fact that conditional release remains an important tool in the treatment of prisoners.

\footnotetext{
1 Jovanić, G. (2012). The standardization process of conditional release as a protection measure of recidivism (Doctoral dissertation). Belgrade: Faculty for Special Education and Rehabilitation.

${ }^{2}$ Stojanović, Z. (1984). Conditional release: problems and perspectives. Proceedings of the Faculty of Law in Zagreb, 34, 1-2.

${ }^{3}$ Simić, B. (2012). Institute of parole in a legislation of the Republic of Serbia. Security 54 (2), 265-276.

${ }^{4}$ Pavlović, Z. (2009). Conditional release in the criminal legislation of Serbia. Law: Theory and Practice, 26 (11-12), 87-100.

${ }^{5}$ Mitrović, L. (2015). Implementation of conditional release in the Republic of Serbia. Yearbook of the Faculty of Law APEIRON, 5 (5), 69-80.

${ }^{6}$ Radoman, M. (2013). Penology and criminal executive law. Belgrade: Medical Edition.
} 
Reviewing papers by local authors dealing with the analysis of the practical application of conditional release in the Republic of Serbia ${ }^{7,8}$ indicates that there are many elements that are not perceived in a satisfactory manner. Thus, most of the sources in this context include primarily peno-historical, criminal and nomotechnical aspects. However, when it comes to the role of special pedagogues/educators in assessing the justification of assigning the given department, and procedures at the request of a convicted person, the given segment appears to be essentially neglected. ${ }^{9}$ These problems are somewhat emphasized by Jovanić, ${ }^{10}$ who indicates in his overarching research the need for standardization of procedural parole and objectification of assessment by experts in penal institutions.

Bearing the previous remarks in mind, the aim of this study is to critically reflect on the legal solution contained in the criminal substantive provisions, and concerning the decision on the justification of granting conditional release. Furthermore, given the recent changes to the Criminal Procedure, ${ }^{11}$ the study focuses on the role of services for treatment, i.e. the evaluation criteria and formulation of treatment programs and ensuing reports. Finally, a summary of different observations from practice, new proposals for the change of (sub)legislation will be formulated, as well as practical guidelines for the work of educators in penal institutions.

\section{Conditional release as a criminal law institute}

The place and role of parole stem from the concept of educational reparability and a vision of the possibility of re-socialization. Thus, starting from the defined purpose of criminal sanctions, and in the segment of special prevention, the basic idea of the treatment of prisoners is organized around the appropriate corrective measures or treatments. It can be expected that the same person will not commit new criminal offenses only by the development of motivation, strengthening the idea of personal responsibility and remorse, and by the development of skills that are essential for convicted pro-social involvement in the community.

Another source of parole framework refers to the fact that the court, regardless of the fact to what extent it respects the principle of individualization of punishment, at the time of sentencing it does not have to dispose of all the relevant data. This relates primarily to personality traits, which condition fulfillment of the imposed sentence to have a different

\footnotetext{
${ }^{7}$ Soković, S. (2014). Conditional release - issues and contemporary normative solutions. CRIMEN, 5 (1), $35-49$.

${ }^{8}$ Stojanović, Z. (1984). Conditional release: problems and perspectives. Proceedings of the Faculty of Law in Zagreb, 34, 1-2.

${ }^{9}$ Simović, M. N., Jovašević, D., \& Simović, V. M. (2015). Parole in the law of the Republic of Serbia and European standards. The harmonisation of legislation with the ACQUIS: collection of works (pp. 69-80). Sarajevo: Centre for Social Research International Burch University.

10 Jovanić, G. (2012). The standardization process of conditional release as a protection measure of recidivism (Doctoral dissertation). Belgrade: Faculty for Special Education and Rehabilitation.

${ }^{11}$ Criminal Procedure (Official Gazette of RS, No. 72/2011, 101/2011, 121/2012, 32/2013, 45/2013 i 55/2014).

${ }^{12}$ Damjanović, I., Kokić-Puce, Z., \& Klarić-Baranović, S. (2004). The conditional release from prison (from 1998. to 2002). Croatian chronicle of Criminal Law and Practice, 11 (2), 867-892.

${ }^{13}$ Kurtović, A. (1995). The organization and legal nature of parole. Proceedings of the Faculty of Law in Rijeka, 10 (2), 309-322.

${ }^{14}$ Jašović, Ž. (2000). Prison Education. Belgrade: Institute for Sociological and Criminological Research.
} 
effect. In this respect, parole may constitute a form of correction of the court or point of re-evaluation of achievement of the purpose of punishment. ${ }^{15}$

Having examined papers of penal and legal orientation, it is often stated that the institute of parole carries an instrumental and even manipulative force in terms of maintaining security in correctional institutions. ${ }^{16}$ The idea that good governance affects the shortening of a sentence carries a presumption of possible influence to convicts in the direction of a higher degree of respect for the house rules. The previous hypothesis is corroborated by certain legal solutions and proposals, which anticipate automaticity in the application of parole for those convicted persons, whose part of the punishment prescribed by law has passed, but who have not been assigned a disciplinary sanction.

Although this argument has implicitly entered the norms and national legislation, it seems that the character of parole is unjustifiably emphasized. Obviously, according to ways of simple logic, conditional release, in this notion, is actually a form of commerce, but also a form of defeat for those who run penal institutions. The idea of "if you behave well you will be released home earlier" not only derogates the court decision, but rather speaks of the impotence of professionals in the Office of Security to maintain order without this kind of corruption.

In brief, parole can primarily be understood as a motivational institute. To be exact, it is difficult to assume that upon entering prison for enforcement of a sentence actually prisoners have the idea that prison is a place of psychological or behavioral correction, as it stands out in the scientific understanding. It seems that from the convict perspective prison is primarily experienced in the retributive context without authentic inner motivation to revise his/her own views.

Consequently, practical effects of conditional release can be used mainly in the segment of encouraging the convicted to accept certain individual goals of treatment, and to actively participate in the implementation of treatment programs. Only in that sense this institute is a place suitable for the purpose of criminal sanctions and the idea of reduction of recidivism.

\section{Behavior of the convicted as criteria in deciding on conditional release}

Referring to the provisions of the Criminal Code, ${ }^{17}$ Article 46 stipulates that the court may conditionally release a convicted person, who has served two thirds of their sentence in prison. ${ }^{18}$ The given solution, thus, seems more restrictive compared to the previous concept, which allows such an option after a lapse of half of the sentence. ${ }^{19}$

\footnotetext{
${ }^{15}$ Pavlović, Z. (2009). Conditional release in the criminal legislation of Serbia. Law: Theory and Practice, 26 (11-12), 87-100.

${ }^{16}$ Soković, S. (2014). Conditional release - contemporary issues and regulatory solutions. CRIMEN, 5 (1), 35-49.

${ }^{17}$ Criminal Procedure (Official Gazette of RS, No. 85/2005, 88/2005 - corr., 107/2005 - corr., 72/2009, $111 / 2009,121 / 2012,104 / 2013$ i 108/2014).

${ }^{18}$ Čejović, B. \& Kulić, M. (2014). Criminal Law. Novi Sad: Faculty of Law for Commerce and Judiciary.

${ }^{19}$ Srzentić, N., \& Lazarević, Lj. (1995). Comment of the Criminal Code of the Republic of Serbia. Beograd: Modern administration.
} 
When deciding on a petition for conditional release, the court takes an assessment of whether during imprisonment the convicted person has improved their conduct in such a way that they can reasonably be expected to behave well when released and in particular that before the expiration of punishment they will refrain from committing a new criminal offense. ${ }^{20}$

This explanation is consistent with the specific purpose of criminal law sanctions. However, such a decision seems to be problematic in several segments. Thus, when assessing the level "of repair" the law specifies that the conduct of the convicted during imprisonment should be taken into account, as well as the performance of work duties and other (undefined) circumstances indicating that in relation to this the purpose of punishment is achieved. ${ }^{21}$

In view of the context of the law and regarding certain educational criteria of correction, the issue of the behavior of prisoners is specifically emphasized. Namely, a frequently expressed opinion of the convicted persons in prisons is that if a person has not been assigned a disciplinary sanction during the enforcement of a sentence, the manifested behavior can be enough evidence of their pro-social adjustment. However, this certainly cannot be taken as reliable evaluation criteria. Respect for the house rules is considered to be a regular obligation of convicts, and their infringement foresees disciplinary measures including coercive measures. This has finally been accurately stated, as well as the content of the previously valid Regulations on measures for maintaining order and security in penal institutions, ${ }^{22}$ where Article 3 indicates that during the execution of the prison sentence the convicted person must act in accordance with the laws and regulations adopted by the law, as per the orders of the officials, except when the execution of the order was an unlawful action. Although the current Rulebook ${ }^{23}$ rejected the given provision, the same continues to be implicitly understood in the context of Article 2, which provides for the same obligation to respect the orders of officials.

The fact that behavior during the enforcement of a sentence cannot be the primary element of the assessment of achieved correction by the convicted, it stands out in relation to the perception of the practice according to which a significant percentage of people in prisons shows highly assertive, even servile behavior. However, this cannot be a priori linked to the internal inspection and correction of pro-criminal attitudes, and it primarily represents the result of situational pressure. ${ }^{24,25}$ The good behavior of physically weaker or stigmatized prisoners (sex offenders) can attribute as a reflection of an emergency that would otherwise bear an increased risk of some form of victimization. ${ }^{26,27}$

\footnotetext{
${ }^{20}$ Stojanović, Z. (2006). Comment of the Criminal Code. Belgrade: Official Gazette.

${ }^{21}$ Simić, B. (2012). Institute of parole in a legislation of the Republic of Serbia. Security, 54 (2), 265-276.

${ }^{22}$ Ordinance on measures for maintaining order and security in the prisons (Official Gazette of RS, No. 105/2006).

${ }^{23}$ Ordinance on measures for maintaining order and security in the prisons (Official Gazette of RS, No. 105/2014).

${ }^{24}$ Kovčo Vukadin, I., \& Mihoci, M. (2010). Violence in penal institutions. Croatian chronicle of Criminal Law and Practice, 17 (1), 333-367.

${ }^{25}$ Krstić, Ž. (2002). The prison's double bottom. Sociology, 44 (3), 223-240.

${ }^{26}$ Pavlović, Z. (2013). Sexual abuse of children - criminological and criminal justice aspects. Novi Sad: Faculty of Law for Commerce and Judiciary.

${ }^{27}$ Pavlović, Z., \& Bijvoets, J. (2016). Situational prevention of child sexual abuse. Science, security, police, 21(1), 114-132.
} 
The behavior problem, as a criterion of 'repairedness', does not end here. Namely, while the Criminal Code in Article 46 stipulates that a convicted person cannot be released on parole if, during the execution of a disciplinary punishment, they were punished twice, or their granted benefits were taken away, the question arises whether the allocation of the extended rights is a sufficient or significant argument regarding the merits conditioning the remainder of their sentence.

Although research such as the one by Jovanic ${ }^{28}$ which was conducted on a sample of 6,326 requests for parole, speaks for the fact that the courts have frequently granted parole to persons who have been granted the extended rights, there are important points to be taken into account in this context. Firstly, inconsistent practices should be noted in a correctional institution or prison, where, in practice, the extended rights in individual institutions were assigned by default, and in conjunction with the specific period of time.

This cannot be justified given the fact that the Law on Execution of Criminal Sanctions ${ }^{29}$ and the Rulebook on treatment, treatment program, classification and subsequent classification of prisoners ${ }^{30}$ stipulate that the extended rights and benefits can be awarded only on the basis of good governance and special efforts in achieving the treatment program and fulfilling individual goals.

The abovementioned problem of behavior assessment is particularly complex in the part related to conditional release, which can be documented by the fact that the law allows for the extended rights to be granted to all prisoners, regardless of their treatment group. In this sense, in practice, it occurs that one of the extended rights is assigned to a person categorized in V-2 group. However, the aforementioned criteria of "good behavior and commitment in achieving treatment program" in the abovementioned category may not be supported by appropriate correction of pro-social attitudes and the degree of risk of recurrence.

Behavior during the enforcement of a sentence is a significant factor in the decisionmaking process for parole only in the case of persons with medium or low risk of recurrence. For persons accommodated in closed wards, or group V-1 or V-2 with a high degree of risk, good conduct and particular commitment are not sufficient criteria. This is accentuated due to the legal implications pursuant to which the mentioned group of persons carries high likelihood of criminal recidivism, as well as the established limits of the capacity for change.

If we allow for the abovementioned statement that good behavior will not be a sufficient criterion to award conditional release to persons who are estimated to have a high degree of criminal recidivism, it can be concluded that the institution will give minimal motivating effect of behavior correction. Namely, if for the specified group of persons justification for the award of parole is predetermined as marginal, the leading mechanism and the reason why the prisoners should act in compliance with the house rules is lost. Ultimately, this leads to the conclusion that conditional release as means of maintaining security within the institution consequently appears to be impotent.

\footnotetext{
${ }^{28}$ Jovanić, G. (2012). The standardization process of conditional release as a protection measure of recidivism (Doctoral dissertation). Belgrade: Faculty for Special Education and Rehabilitation.

${ }^{29}$ Law on Enforcement of Penal Sanctions (Official Gazette of RS, No. 55/2014).

${ }^{30}$ Rulebook on treatment, treatment program, classification and subsequent classification of prisoners (Official Gazette of RS, No. 66/2015).
} 
At this point, however, we need to address the results of the research conducted by Jovanić. ${ }^{11}$ According to his findings, among persons categorized in the $\mathrm{V}-1$ and $\mathrm{V}-2$ group of 62 reviews of institutions for parole, the reports were positive in as many as 17 cases $(27.4 \%)$. The same source also indicates that, in the given sample, in 6 cases $(9.5 \%)$ conditional release was also granted by the court.

Following the previous remarks, it would be favorable to consider nearly a third of specific cases in which the institution is established for persons bearing a high risk of recurrence, and it is reasonable to expect that, when released, they will not commit new criminal offenses. In effect, it would be vital to determine how the convicted person's limited capacity for change was established, while they carry a significant risk of security breach in the institution. Nevertheless, they can be released on parole for the remainder of the sentence.

By further analysis of the existing legal framework, the significance of conduct during the enforcement of a sentence is particularly viewed in a negative context, i.e. within behaviors bearing a disciplinary sanction. ${ }^{32}$ Nevertheless, there are several problems in this segment, as well. Namely, not only the Criminal Code does fail to distinguish minor and serious disciplinary offenses, but it leaves the possibility of significant conflict of clinical and formal-legal aspects. Thus, guided by Article 36 of the Rules on the Treatment, it is anticipated that the convicted person may be subsequently classified into a group with a lesser degree of the extended rights and benefits as a result of a disciplinary punishment for a minor offense.

The aforementioned optional framework allows the convicted person, who has been categorized in A-1 group to make two minor disciplinary offenses without being recategorized into a group with the lower frame of law or without getting deprived of the previously granted extended rights for the same reason. Although low criminal recidivism was estimated during the assessment, the fact that a person was twice disciplined eliminates the legal possibility of awarding conditional release.

The problems of assessing the conditions for awarding conditional release to prisoners can be observed in the other examples from practice. For instance, it happens that during admission the person is put in B-1 category with the established medium risk, a level of 33 points. The same convict was awarded more extended rights including noncustodial, which were used without abuse. However, during the enforcement of a sentence the convict gets into physical conflict with another convicted person and the circumstances impose more severe disciplinary measures like deprivation of the extended rights. In the same scenario, during the re-evaluation of the degree of risk a negative correction can be made, and the convict remains at medium level with 38 points alongside with re-categorization into group $\mathrm{V}-1$, and they are moved to a closed ward.

Furthermore, if the convicted person has denied their benefits, they will not meet the normative framework of Article 46 of the Criminal Code. Therefore, their conditional release will not be approved. However, this example can be compared to a person who is in the semi-class and group B-2, with no assigned extended rights, which may also have

\footnotetext{
${ }^{31}$ Jovanić, G. (2012). The standardization process of conditional release as a protection measure of recidivism (Doctoral dissertation). Belgrade: Faculty for Special Education and Rehabilitation.

32 Ilijić, Lj., \& Jovanić, G. (2014) Disciplinary punishment of the damned. Insitute of Criminological and Sociological Research, 33 (2), 163-176.
} 
a medium level of risk, and fixed at the level of 52 points. In the given comparison, although the risk assessment questionnaire clearly provides better prediction of criminological recidivism in the first case, the Criminal Code gives priority to the person with the higher number of points, but in the context of conditional release.

\section{Work as a criterion for deciding on conditional release}

The second segment of the legal framework concerning conditional release refers to the work of the convicted as the assessment of the justification of the award criteria of the mentioned institute. Although Article 98 of the PSEA foresees that the work of the convicted is an integral part of the treatment, it is not conditioned as an obligation, but merely as a treatment option. In this sense, it is questionable whether the person who refuses the opportunity to be engaged in work, by default, cannot meet the necessary criteria for the award of conditional release.

Looking back at the aforementioned experiences from practice, the answer to this question becomes highly complex. Thus, for example, there were cases in which a person during the execution of a sentence was continuously engaged in work, which is the reason why that person received the appropriate extended rights. However, following the restrictions of the Questionnaire for the risk assessment for persons sentenced to imprisonment up to three years, the risk level reduction associated with work engagement is possible only at a negligible level. ${ }^{33}$ In this regard, although work is characterized in the Criminal Code as a vital criterion for the evaluation, the development of working habits in the abovementioned questionnaire grants maximum 2 points out of the total of 106 points.

The list of issues related to the work as a variable in estimating prisoners becomes problematic considering another indisputable fact. According to the data presented in the reports of the Helsinki Committee for Human Rights, ${ }^{34}$ the number of working-age convicts does not exceed one third in most penal institutions. In this sense, the question is whether the lack of jobs points to the responsibility of the state in terms of failure to ensure minimum conditions of treatment, or may be viewed as a circumstance, which indicates that the convicted person has not developed working habits, regardless of the direction of accountability. Therefore, is it fair to say that the absence of work engagement, for any reason, necessarily means a lack of positive response to the prisoner request for parole?

In summary of the abovementioned arguments, it appears that the legal text, though logically sustainable per se, is in a significant conflict with other legal and sub-legal segments, and it is also inconsistent with the current professional practice. Work as a segment of the educational course correction holds an absolutely justified place in treatment facilities. ${ }^{35}$ However, the literal interpretation of the existing legal text would have to be verified regarding the hypothesis according to which persons engaged in work, who have

\footnotetext{
${ }^{33}$ Petković, N., \& Pavlović, Z. (2016). Some problems in applying the "Questionnaire for the risk assessment for those sentenced to imprisonment up to three years". Temida, 19 (1), 161-189.

${ }^{34}$ Helsinki Committee for Human Rights (2016). The situation in prisons in Serbia. Taken from: http://www.helsinki.org.rs (date of access: 12 April 2016).

${ }^{35}$ Jašović, Ž. (2000). Prison Education. Belgrade: Institute for Sociological and Criminological Research.
} 
shown adequate commitment at work during the execution of a sentence have a lower rate of criminal recidivism risk. Only by establishing a positive correlation between the listed dependent and independent variables a conclusion could be drawn on the justification of incorporating labor as an element of assessment in the legal text.

Finally, assessing the work done by convicts who are serving sentence at this moment seems to be entirely unadjusted in the context of the topic of conditional release. While scientific literature highlights work engagement as desirable for economic reasons and for the sake of organizing the excess of free time that convicts have, ${ }^{36}$ it becomes questionable whether it is justified to say that the work itself is the holder of correctional education. Although the authors such as Jašović ${ }^{37}$ suggest that production work has an insuperable value in rehabilitation and re-socialization, change of beliefs and the worldview, as well as the adoption of positive attitudes, a more correct conclusion would seem to be that work training and skills development are the bearers of positive resources that reduce the likelihood of recurrence.

Namely, a certain percentage of people who are serving prison sentences have no primary education or the minimum skills in certain crafts. ${ }^{38}$ Only the acquisition of appropriate knowledge and skills in a specific field could carry the potential for a convicted person, for example, the one sentenced for property crimes, that after the expiration of their sentence, and strengthened by new capacities, they could find employment instead of turning to crime again.

However, let us imagine the scenario in which a car mechanic, prone to alcohol abuse, convicted of domestic violence, imprisoned for a year-long execution of sentence, is allocated a job as a co-worker in the prison garage. Can his outstanding engagement in restoring the outdated vehicle fleet be really regarded as a sufficient criterion of "repair"? It does not seem to be the case!

\section{Individual goals as other circumstances during imprisonment}

The existing legal and sub-legal framework of criminal sanctions bears fairly good assumptions concerning the need for the convicted person at the start of serving their execution of prison sentence to be observed by experts from the corresponding fields. ${ }^{39}$ Additionally, after staying in the admission department, specific individual goals are foreseen, ones which will practically dictate the flow of the program of conduct.

However, when it comes to individual treatment goals, which constitute the core of subsequent (methodology of) re-socialization, the legislator is rather vague. Although Article 13 of the Rules on the Treatment states that this will ensure the achievement of individual goals to increase the individual's capacity, successful adaptation and reduction of the risk of committing criminal acts, it lacks more detailed elaboration.

\footnotetext{
${ }^{36}$ Uggen, C. (2000). Work as a turning point in the life course of criminals: a duration model of age, employment, and recidivism. American sociological review, 65 (4), 529-546.

37 Jašović, Ž. (2000). Prison Education. Belgrade: Institute for Sociological and Criminological Research.

${ }^{38}$ Odović, G., Žunić-Pavlović, V., \& Jovanić, G. (2014). Professional training as a factor in the rehabilitation of convicted persons in the institutions for enforcement of prison sentence. U G. Nedović \& G. Odović (ur.). III International Scientific Conference Special Education and Rehabilitation - Adults with Disabilities (pp. 353-366). Belgrade: Faculty for Special Education and Rehabilitation, Department of Somatopedy.

${ }^{39}$ Radoman, M. (2013). Penology and criminal executive law. Belgrade: Medical Edition.
} 
The Directive on the work of treatment officers in institutions is set only as a reference point (No. 110-00-1/13-03 of $24^{\text {th }}$ February 2013), stating that in defining procedures and activities for the convict individual objectives and their implementation dates must be defined. The same document conditions that the objectives must be established on the grounds of test results, and they must be clear, measurable, and time-bound, while the maximum number is limited to five.

Guided by the further content of the mentioned Directive, institutions for enforcement of criminal sanctions were submitted the appropriate annex containing the explication of general objectives for all the convicted, as well as individual goals that are awarded according to the established needs. However, the text of the document states that employees of the Office can implement the mentioned objectives, but without defining imperatives. The same can be observed in the Directive on the means of treatment in prisons, work procedures and the design and content of documents during the identification, implementation and change of the program dealing with individuals convicted of crimes and misdemeanor, and the method of application of the Ordinance on treatment, treatment program, classification and subsequent classification of prisoners (number 110-00-00014/2015-01 dated 29 ${ }^{\text {th }}$ October 2015), which only contains nonbinding examples of individual goals.

Analyzing subordinate normative framework, it should be noted that the draft of objectives as set by the Directive includes the content of rather heterogeneous framework, whose implementation does not always refer to contributions in the context of special criminological prevention of recidivism.

Furthermore, although the authors such as Aćimović ${ }^{40}$ point out that inmates, who participate in group model work in prisons are primarily driven by intrinsic motivation and a desire to improve their own personality, the authors of this paper, guided by practical experience, do not share such optimism. In this sense, participation in treatment programs, although it may be of (general) benefit to the convicted persons, must bear a more concrete assessment of the achievement impact in the context of reduction of recurrence risk. This is especially significant due to different experiences worldwide, which indicate that participants in specialized programs in penal conditions not only have the annuitant attitude towards taking part in the programs, but often adjust their testimonies to the expectations of the program leader, without actually correcting their own attitudes. ${ }^{41,42,43}$

There are numerous examples which point to the fact that (sub)legislation does not work best in practice when it comes to implementing measures to reduce criminal recidivism. For instance, we can imagine a situation in which the convicted person was assigned the following individual goals: "Developing and maintaining working habits", "Increasing health care" and "Organization and participation in leisure activities." However, given the limited need for labor in the institution, the convict will work only three days a month. Moreover, given the fact that the goal of "Increasing health care" is predominantly

\footnotetext{
${ }^{40}$ Aćimović, D. M. (2013) Implementation and evaluation of group forms with the work with convicts, case study of Novi Sad. Andragoške studije, (2), 137-148.

${ }^{41}$ Kokish, R. (2004). The current role of post-conviction sex offender polygraph testing in sex offender treatment. Journal of Child Sexual Abuse, 12 (3-4), 175-194.

${ }^{42}$ Lotringer, S. (2007). Overexposed: Perverting perversion. New York: Pantheon.

${ }^{43}$ Pavlović, Z. (2009). Conditional release in the criminal legislation of Serbia. Law: Theory and Practice, 26 (11-12), 87-100.
} 
assessed through accepting cooperation with the Health Service, the convict accepts and is subjected to regular medical inspections. Finally, the convicted person may be involved in the Sports and Arts Section, whereby they express initiative, actively and regularly participate thus organizing their free time.

In summary of all the above mentioned, we are faced with a peculiar situation in which the convicted person was formally work-engaged, established a satisfactory relationship with the Health Service and regularly attended the Sports Section, having practically fulfilled all the assigned individual objectives. However, can the fact that they regularly visited the doctor and played basketball for a year be taken as solid grounds to assume that having such an achieved degree of correctional education the convicted person, when released, will not commit new crimes?

By further analysis of the content of the Directive, it is noted that the nonbinding nature of this act has led to the absence of standardized framework for the identification of convicts' needs, the appointment of treatment objectives, and their allocations. In practice, this means that every penal institution in Serbia can have its own model of establishing individual goals, as well as their evaluation, without any uniformity of operation or confirmation of reliability assessment.

The following instance illustrates that the aforementioned situation leads to numerous problems. For example, a person sentenced to imprisonment for a term of 2 years may be granted an individual goal in a correctional institution (whose implementation has not been completed), and subsequent to their transfer to the county prison to serve the same sentence, the assigned goal is not even recognized. Ultimately, if there is any compatibility of the appointment of goals, it is likely that their fulfillment is monitored using dissimilar instruments, which certainly points to the problem of comparison of the current effects.

Furthermore, the question is whether, after the formulation of a broader list of individual goals, it would be justified to formulate some recommendations concerning their adoption. For example, all convicts convicted of (minor/serious) physical injury, murder, bullying and similar offences, need to be covered by a specific individual goal, which concerns non-violent resolution of interpersonal conflicts. Such is the case with persons who are perpetrators of crimes against sexual freedom or, for instance, persons convicted for offenses related to drug use, and in the context of compatible objectives.

Having returned to observations in practice, it is obvious that in addition to the arbitrariness in the appointment of unstandardized individual goals, the same level applies to the content and forms of their implementation. This particularly applies to the contents of specialized programs and educational workshops. Thus, for example, in some institutions in Serbia individual goals are presented as "Problem solving and decision-making", which is again implemented through the educational workshop entitled "Constructive problem solving." ${ }^{44}$ Thereby, not only it is unclear who the mentioned objective is defined for, but the question is in what way the content of the specific workshop was formed, and the same thing is brought into connection with the reduction of a relapse.

To remain in the same context, the largest segment of educational workshops in penal institutions in Serbia, whether and where they are organized at all, is the result of the indi-

\footnotetext{
${ }^{44}$ Aćimović, D. M. (2013). Implementation and evaluation of group forms with the work with convicts, case study of Novi Sad. Andragoške studije, (2), 137-148.
} 
vidual contributions of employees. However, their content is usually insufficiently scientifically based and empirically not tested in a penal context. This is mainly related to the attempts to adapt the knowledge acquired while working with unconvicted population. ${ }^{45}$

It stands out that the aforementioned is completely unjustified due to the development and availability of various effective treatment programs. Therefore, in contemporary references there are dozens of different described and evaluated program options aimed at perpetrators of virtually all crimes. ${ }^{46,} 47,48$ Additionally, while having respect for linguistic limitations pertaining to the review of foreign sources, it should be noted that national authors have devoted ample attention to the subject. ${ }^{49}$, ${ }^{50}$ Consequently, re-socialization program activities should rightly be expected to be in accordance with scientific requirements.

Although we did not want to take this opportunity to criticize the contributions of experts in penal institutions, which are certainly an expression of positive aspirations to improve professional work, it seems to be unjustified to expect that the indirect executors, i.e. educators are the ones who will formulate the basic assumptions of the treatment of prisoners. However, the obligation of the Board for Implementation appears unequivocal by which, in addition to defining and listing individual goals, their implementation framework should also be clearly defined.

Let us return to the topic of conditional release. The methodology of re-socialization dictates that when a convicted person is assigned an individual goal, its fulfillment must be monitored in a certain way. Thus, concerning the evaluation of re-socialization ŽunićPavlovic ${ }^{51}$ in her work clearly highlights all the criteria that are important for assessing the effectiveness of a program. However, the situation in practice is again limited to the ingenuity of educators and their not tested idea on how to follow a certain goal.

In penal institutions, assigned individual goals are monitored through an appropriate "watch list". In addition, the given framework represents an attempt to form certain instruments that carry some form of quantification of the progress made, as well as a qualitative description.

In the objectives which are appointed by the Directive, the "watch lists" are by content adapted to the given recommendations. Nevertheless, the problems do not end here. For instance, while the individual goal of "Establishing and maintaining functional family relationships" definitely finds its justification in a number of cases, there remains the question of its monitoring. Accordingly, the 2013 Directive stipulates that the same will be followed through

\footnotetext{
${ }^{45}$ Aćimović, D. M. (2013). Implementation and evaluation of group forms with the work with convicts, case study of Novi Sad. Andragoške studije, (2), 137-148.

${ }^{46}$ Marques, J. K., Wiederanders, M., Day, D. M., Nelson, C., \& Van Ommeren, A. (2005). Effects of a relapse prevention program on sexual recidivism: Final results from California's Sex Offender Treatment and Evaluation Project (SOTEP). Sexual Abuse: A Journal of Research and Treatment, 17 (1), 79-107.

${ }^{47}$ Andrews, D. A., Bonta, J., \& Wormith, J. S. (2011). The risk-need-responsivity (RNR) model: does adding the good lives model contribute to effective crime prevention?. Criminal Justice and Behavior, 38 (7), 735-755.

${ }^{48}$ McLaren, K. (1992). Reducing reoffending: What works now. Wellington: Penal Division, Department of Justice.

${ }^{49}$ Petković, N., \& Pavlović, Z. (2016). Abuse and neglect of children in Serbia. Belgrade: Institute for Sociological and Criminological Research.

${ }^{50}$ Popović-Ćitić, B. (2013). Principles of effective prevention programs. Social thought, 20 (1), 103-116.

${ }^{51}$ Žunić-Pavlović, V. (2004). Evaluation in resocialization. Belgrade: Partenon.
} 
checking the frequency of visits, received letters, telephone contacts with the family, accepting to participate in family meetings, and assessing the quality of family relationships.

Looking at experiences from practice, we can, for example, observe a situation that a convict regularly receives letters and parcels, and/or regularly has family visits. Nevertheless, this fact does not say anything about the actual quality of family relationships (or about the correction of the convict's attitude in relation to, for example, a criminal offense against marriage and family) which the educator is only indirectly informed about. In addition, the question arises whether through the implementation of individual goals it could be considered that a convict, who has had six visits in a given period, has improved to a greater extent than the convicted person who has not had a single visitor. This stands out due to the significant number of prisoners who have a difficult financial situation that, in turn, limits the family members to travel outside a town.

The situation is similar with other goals, such as "Healing addiction / establishing and maintaining abstinence". Accordingly, this would primarily lead to the conclusion that the establishment and maintenance of abstinence is the logical consequence of their imprisonment, having in mind the lack of access to drugs. Only if the individual misused psychoactive substances in some way, it would be considered a disciplinary offense. In that sense, respect for the house rules is an obligation of the convicted person, not a goal whose fulfillment can be correlated with the reduction of the recidivism risk.

Furthermore, relative to the contents of the mentioned 2013 Directive, the proposal of monitoring the abovementioned objective includes the development of motivation to change the old ways of life, requesting or accepting the help of others when needed, and recognition of circumstances and risk factors that lead to a relapse. Although somewhat logically sustainable, this is disputable for several reasons.

Thus, a significant number of modern program contents that are designed for some form of correction of attitudes and behaviors are evaluated by the principle of test-retest model, i.e. baseline characteristics are established and the dependent variables changed subsequently to participation in a program. ${ }^{52,53,54}$ However, if we imagine a heroin addict who has been repeatedly treated on their own initiative, who is intelligent, well aware of the consequences of drug abuse, has acquired knowledge about risk factors and emotional turbulence as triggering factors before coming to the execution of a sentence, can they be considered to have achieved the assigned individual target (in the largest segment) before its implementation started? Finally, would the fact that a convict has regularly used substitution therapy, visited a psychiatrist and expressed pro-social intentions, really prove their commitment to the establishment of permanent abstinence and a lower risk of recurrence of the criminal act? For this reason, there is a need to define the pre-

\footnotetext{
${ }^{52}$ Schuringa, E., Spreen, M., \& Bogaerts, S. (2014). Inter-rater and test-retest reliability, internal consistency, and factorial structure of the instrument for forensic treatment evaluation. Journal of Forensic Psychology Practice, 14 (2), 127-144.

${ }^{53}$ Rees-Jones, A., Gudjonsson, G., \& Young, S. (2012). A multi-site controlled trial of a cognitive skills program for mentally disordered offenders. BMC Psychiatry, 12 (1), 12-44.

${ }^{54}$ Klepfisz, G., O’Brien, K., \& Daffern, M. (2014). Violent offenders' within-treatment change in anger, criminal attitudes, and violence risk: associations with violent recidivism. International Journal of Forensic Mental Health, 13 (4), 348-362.
} 
cise content of treatment to determine a baseline and post-program evaluation point, which would in this regard facilitate the quantifying of the achieved progress.

The example of the individual goal called "Proper use of special rights outside the institution" illustrates that the proposed set of goals is often outside the context of risk reduction and special prevention. Thus, the given objective, pursuant to the Directive, is monitored by means of record-keeping regarding the behavior of the convicted person and their usage of benefits without abuse and their establishment of a relationship with the family.

In fact, when it comes to awarding non-custodial law, the same shall be done in cases where the convicted person has deserved such a benefit by their behavior and commitment to the program. Respect for the rules related to the conduct of the convicted person outside the institution, for example during weekends, does not seem logical to be defined as an objective. The proper use of non-custodial law is considered to be an obligation, whose non-compliance leads to disciplinary sanctions, and as a rule, to consequential re-categorization.

A particular problem in the evaluation of individual objectives relates to participation in specialized programs and educational workshops, which should logically be the most potent treatment segment. However, unlike the scientific demands of reliability and verifiability, the educators' attempts to formulate assessment instruments in national penal institutions are an expression of mere arbitrariness. The variables contained are the result of an agreement at the level of individual institutions, and they are not scientifically proven elements. The watch lists hence usually include three-point or five-point scales on the items at makeshift, where the practice indicates that negative reviews are given, as a rule, only to those prisoners who renounce participating in group work.

In summary of the abovementioned arguments, the assessment of achievement of individual goals at the level of the Directorate for Execution of Criminal Sanctions in Serbia would require the formulation of scientifically based and proven program curricula and evaluation instruments. It is exactly in this context that the most important conclusions concerning conditional release are imposed. Only in a situation where there is no clearly defined treatment goal, in a situation in which the contents of the fulfillment of individual targets are not precisely defined, or in a situation where there is no reliable monitoring mechanism achieved, the question is what exactly the ground of conclusion of experts employed in the Service for Treatment is in (thousands of) applications for parole.

\section{References for practice - in lieu of conclusion}

On the subject of parole, in some countries, such as the USA, approximately $80 \%$ of cases at the request of the convicted person are given a positive response. ${ }^{55}$ However, in contrast to seemingly insufficiently selective jurisprudence in the United States, conditional release in the Republic of Serbia is awarded only in exceptional cases. Only when it is fully justified to expect that the released person will not commit new crimes, the criminological and victim logical aspects of penalty can substantiate that the convict should be released earlier from serving the sentence.

\footnotetext{
${ }^{55}$ Jovanić, G. (2012). The standardization process of conditional release as a protection measure of recidivism (Doctoral dissertation). Belgrade: Faculty for Special Education and Rehabilitation.
} 
In the same context, the positive assessment of the justification of the proposal by the institution requires fulfillment of strict scientific criteria and the absence of arbitrariness and subjectivity. In this sense, it appears necessary to change the basic settings of the Service for Treatment in the Directorate for Execution of Criminal Sanctions, as the instance which is responsible for the context of formulating reports on the convicted necessary in the procedure for conditional release.

Summing up previous observations, there is primarily the need of significant correction of convicts assessment instruments stipulated in the Regulation on the treatment and separation of security risk and relapse. ${ }^{56}$ Furthermore, there is requirement for the standardization of treatment activities and the introduction of contents, whose effectiveness is proven in practice. However, this does not have to involve only the incorporation of previously used foreign programs. It also allows for the full creativity of local experts and devising new curricula with respect to all scientific and evaluative requirements.

The fact that there is a need for the formulation of clear evaluation criteria stands out in comparison to the aforementioned annuity nature of the conduct of the convicted. For instance, some observations suggest that in practice convicts are actually employed during the execution of a sentence, and then for several months they give a certain sum of money (not exceeding a few thousand dinars) to charity. This action could, on the one hand, be interpreted as an expression of remorse and an attempt of reparation, which is certainly positive in the context of an application for conditional release. However, whether it is genuine remorse or an object of manipulation, it must certainly be determined through appropriate instrumentation and objective clinical assessment.

The same conclusions apply to the fulfillment of short-term and long-term plans for post-penal convicts, as well. In fact, one of the possible ways of assessment, in the context of conditional release, refers to what the former convict actually plans after their release from prison. If the person has been provided with employment, they can be expected to have a source of income and some form of social inclusion, so a positive prediction could be given with a greater degree of certainty. However, the state of facts in the present-day social situation shows that numerous convicts obtain various (false) certificates, which indicate that they are employed in private firms. However, the fact is that they have not stepped an inch further away from pro-criminal orientation.

In summary of the above mentioned, the question arises whether it is justified that if during the execution of a sentence the convict shows good (annuity) behavior, is given (automatically) the extended rights, if medium or low risk has been determined (using a questionnaire whose reliability is questionable), ${ }^{57}$ if he expresses (inauthentic) remorse and pro-social goals, and if he provides a certificate (guaranteeing nothing) that a job awaits him on the same day after his release from prison - is not granted a positive opinion by the Department for Treatment in the context of an application for conditional release? Within the existing provisions, he would certainly be granted one. Nevertheless, the decision must be well substantiated.

\footnotetext{
${ }^{56}$ Petković \&Pavlović (2016). Some problems in applying the "Questionnaire for the risk assessment for those sentenced to imprisonment up to three years". Temida, 19 (1), 161-189.

${ }^{57}$ Petković \&Pavlović (2016). Some problems in applying the "Questionnaire for risk assessment sentenced to imprisonment up to three years". Temida, 19 (1), 161-189.
} 
The assessment of achievement of the purpose of criminal sanctions, i.e. the prediction of social rehabilitation must therefore include only those variables that have been proven in connection with the reduction of the special relapse. This is especially significant because of the fact that since the amendment of the Criminal Procedure, the courts explicitly require the institution to determine whether they do or do not propose that the convicted person should be released on parole.

Although the reported attitude of the institution is not legally binding on the court decision, it is an ethical and professional imperative that the institution report be based on the principles of objective and reliable assessment, which substantially aids the court's decision-making, strengthens the penal policy and raises the professional reputation of professionals, who work in the Department for Treatment.

The issue of objectification and standardization of evaluating the prisoners in the context of conditional release is of particular importance and it stands out in comparison to the observed law case. Namely, with reference to the work by Jovanić, ${ }^{58}$ we can see that although the reports from the institution, where the sentence is executed clearly indicate the unjustified allocation of conditional release, the court still grants it for the rest of the sentence. This situation not only devalues the importance of treatment and expert evaluation during the execution of a sentence, but it poses the objective question whether educators/facilitators of treatment can be observed in the specific, informal status of an expert witness, or their role is merely advisory and aesthetic. Finally, the need and possibility of limiting judicial review are also questioned, given the fact that the court deciding on conditional release practically has no other means of obtaining information on the convicted person from the moment of final judgments and decisions of the executive up to the submission of an application for conditional release.

\section{References}

[1] Andrews, D. A., Bonta, J., \& Wormith, J. S. (2011). The risk-need-responsivity (RNR) model: does adding the good lives model contribute to effective crime prevention? Criminal Justice and Behavior, 38 (7), 735-755.

[2] Aćimović, D. M. (2013). Implementacija i evaluacija grupnih formi rada sa osuđenicima-studija novosadskog slučaja. Andragoške studije, (2), 137-148.

[3] Čejović, B. \& Kulić, M. (2014). Krivično pravo. Novi Sad: Pravni fakultet za privredu i pravosuđe.

[4] Damjanović, I., Kokić-Puce, Z., \& Klarić-Baranović, S. (2004). Uvjetni otpust s izdržavanja kazne zatvora (od 1998. do 2002). Hrvatski ljetopis za kazneno pravo i praksu, 11 (2), 867-892.

[5] Direktiva o načinu rada službenika tretmana u zavodima, procedurama u radu i izgledu i sadržaju dokumenata tokom utvrđivanja, sprovođenja i izmene programa postupanja sa licima osuđenim za krivična dela i prekršaj, i načinu primene Pravilnika o tretmanu, razvrstavanju i naknadnom razvrstavanju osuđenih lica (broj 110-00-00014/2015-01). (2015). Beograd: Ministarstvo pravde i državne uprave - Uprava za izvršenje krivičnih sankcija.

[6] Direktiva o načinu rada službenika tretmana u zavodima, procedurama u radu i izgledu i sadržaju dokumenata tokom utvrđivanja, sprovođenja i izmene programa postupanja sa licima osuđenim za krivična dela i prekršaj, i načinu primene Pravilnika o tretmanu, razvrstavanju i naknadnom razvrstavanju osuđenih lica (broj 110-00-1/13-03). (2013). Beograd: Ministarstvo pravde i državne uprave - Uprava za izvršenje krivičnih sankcija.

\footnotetext{
${ }^{58}$ Jovanić, G. (2012). The standardization process of conditional release as a protection measure of recidi-
} vism (Doctoral dissertation). Belgrade: Faculty for Special Education and Rehabilitation. 
[7] Helsinški odbor za ljudska prava (2016). Stanje u zatvorima u Srbiji. Downloaded: http://www.helsinki.org.rs (datum pristupa: 12. april 2016).

[8] Ilijić, Lj., \& Jovanić, G. (2014) Disciplinsko kažnjavanje osuđenih. Zbornik Instituta za kriminološka i sociološka istraživanja, 33 (2), 163-176.

[9] Jašović, Ž. (2000). Penološka andragogija. Beograd: Institut za sociološka i kriminološka istraživanja.

[10] Jovanić, G. (2012). Standardizacija postupka uslovnog otpusta kao mera zaštite od recidivizma (Doktorska disertacija). Beograd: Fakultet za specijalnu edukaciju i rehabilitaciju.

[11] Klepfisz, G., O'Brien, K., \& Daffern, M. (2014). Violent offenders' within-treatment change in anger, criminal attitudes, and violence risk: associations with violent recidivism. International Journal of Forensic Mental Health, 13 (4), 348-362.

[12] Kokish, R. (2004). The current role of post-conviction sex offender polygraph testing in sex offender treatment. Journal of Child Sexual Abuse, 12 (3-4), 175-194.

[13] Kovčo Vukadin, I., \& Mihoci, M. (2010). Nasilje u penalnim ustanovama. Hrvatski ljetopis za kazneno pravo i praksu, 17 (1), 333-367.

[14] Krivični zakonik. (2005). Sl. glasnik RS, br. 85/2005, 88/2005 - ispr., 107/2005 - ispr., 72/2009, 111/2009, 121/2012, 104/2013 i 108/2014.

[15] Krstić, Ž. (2002). Zatvorsko duplo dno. Sociologija, 44 (3), 223-240.

[16] Kurtović, A. (1995). Ustrojstvo i pravna priroda uvjetnog otpusta. Zbornik Pravnog fakulteta u Rijeci, 10 (2), 309-322.

[17] Lotringer, S. (2007). Overexposed: Perverting perversion. New York: Pantheon.

[18] Marques, J. K., Wiederanders, M., Day, D. M., Nelson, C., \& Van Ommeren, A. (2005). Effects of a relapse prevention program on sexual recidivism: Final results from California's Sex Offender Treatment and Evaluation Project (SOTEP). Sexual Abuse: A Journal of Research and Treatment, 17 (1), 79-107.

[19] McLaren, K. (1992). Reducing reoffending: What works now. Wellington: Penal Division, Department of Justice.

[20] Mitrović, L. (2015). Primjena uslovnog otpusta u Republici Srpskoj. Godišnjak Fakulteta pravnih nauka APEIRON, 5 (5), 69-80.

[21] Odović, G., Žunić-Pavlović, V., \& Jovanić, G. (2014). Profesionalno osposobljavanje kao faktor rehabilitacije osuđenih lica u ustanovama za izvršenje kazne zatvora. U G. Nedović \& G. Odović (ur.). III međunarodna naučna konferencija Specijalna edukacija i rehabilitacija - Odrasle osobe sa invaliditetom (str. 353-366). Beograd: Fakultet za specijalnu edukaciju i rehabilitaciju, Odeljenje za somatopediju.

[22] Pavlović, Z. (2009). Uslovni otpust u kaznenom zakonodavstvu Srbije. Pravo: teorija $i$ praksa, 26 (11-12), 87-100.

[23] Pavlović, Z. (2013). Seksualna zloupotreba dece - kriminološki i krivičnopravni aspekti. Novi Sad: Pravni fakultet za privredu i pravosuđe.

[24] Pavlović, Z., \& Bijvoets, J. (2016). Situational prevention of child sexual abuse. Nauka, bezbednost, policija, 21(1), 114-132.

[25] Petković, N., \& Pavlović, Z. (2016a). Neki problemi u primeni "Upitnika za procenu rizika za osuđene na kaznu zatvora do i tri godine". Temida, 19 (1), 161-189.

[26] Petković, N., \& Pavlović, Z. (2016b). Zlostavljanje i zanemarivanje dece u Srbiji. Beograd: Institut za sociološka i kriminološka istraživanja.

[27] Popović-Ćitić, B. (2013). Principi efektivnih preventivnih programa. Socijalna misao, 20 (1), 103-116. 
[28] Pravilnik o merama za održavanje reda i bezbednosti u zavodima za izvršenje zavodskih sankcija. (2006). Sl. glasnik RS, br. 105/2006.

[29] Pravilnik o merama za održavanje reda i bezbednosti u zavodima za izvršenje zavodskih sankcija. (2014). SI. glasnik RS, br. 105/2014.

[30] Pravilnik o tretmanu, programu postupanja, razvrstavanju i naknadnom razvrstavanju osuđenih lica. (2015). SI. glasnik RS, br. 66/2015.

[31] Radoman, M. (2013). Penologija i kazneno izvršno pravo. Beograd: Medicinska naklada.

[32] Rees-Jones, A., Gudjonsson, G., \& Young, S. (2012). A multi-site controlled trial of a cognitive skills program for mentally disordered offenders. BMC Psychiatry, 12 (1), 12-44.

[33] Schuringa, E., Spreen, M., \& Bogaerts, S. (2014). Inter-rater and test-retest reliability, internal consistency, and factorial structure of the instrument for forensic treatment evaluation. Journal of Forensic Psychology Practice, 14 (2), 127-144.

[34] Simić, B. (2012). Institut uslovnog otpusta u pozivnom zakonodavstvu Republike Srbije. Bezbednost, 54 (2), 265-276.

[35] Simović, M. N., Jovašević, D., \& Simović, V. M. (2015). Uslovni otpust u pravu Republike Srbije i evropski standardi. U Usklađivanje zakonodavstva s ACQUIS-em: zbornik radova (str. 69-80). Sarajevo: Centar za društvena istraživanja Internacionalnog Burč univerziteta.

[36] Soković, S. (2014). Uslovni otpust - sporna pitanja i savremena normativna rešenja. CRIMEN, 5 (1), 35-49.

[37] Srzentić, N., \& Lazarević, Lj. (1995). Komentar Krivičnog zakona Republike Srbije. Beograd: Savremena administracija.

[38] Stojanović, Z. (1984). Uslovni otpust: problemi i perspektive. Zbornik Pravnog fakulteta $u$ Zagrebu, 34, 1-2.

[39] Stojanović, Z. (2006). Komentar Krivičnog zakonika. Beograd: Službeni glasnik.

[40] Uggen, C. (2000). Work as a turning point in the life course of criminals: a duration model of age, employment, and recidivism. American sociological review, 65 (4), 529-546.

[41] Zakon o izvršenju krivičnih sankcija. (2014). Sl. glasnik RS, br. 55/2014.

[42] Zakonik o krivičnom postupku. (2011). Sl. glasnik RS, br. 72/2011, 101/2011, 121/2012, 32/2013, 45/2013 i 55/2014.

[43] Žunić-Pavlović, V. (2004). Evaluacija u resocijalizaciji. Beograd: Partenon. 